\title{
PDT for Cultured Cancer Cell by 5ALA-induced Protoporphyrin IX \\ 5ALAより誘導されるプロトポルフィリンIXを用いた 培養癌細胞へのPDT
}

\author{
Kunio AWAZU 1.2 \\ 粟津 邦男 ${ }^{1.2}$
}

\author{
1, Laser Biology Research Laboratory \\ The University of Texas M. D. Anderson Cancer Center \\ 2, Free Electron Laser Research Institute \\ Correspondence : Free Electron Laser Research Institute \\ 4547-44, Tsuda, Hirakata, Osaka 573-01, Japan \\ 自由電子レーザ研究所 \\ 于573-01 大阪府枚方市津田4547-44 \\ TEL 0720-96-0417 FAX 0720-96-0421
}

\begin{abstract}
Photodynamic therapy, PDT, has mainly been done using a laser system and a fluorescence dye which can be absorbed in a targeted cell culture or tumor. Establishing effective protocols of laser irradiation requires a knowledge of the local concentration of the dye in the target.

In this paper, Protoporphyrin IX that can be induced by $\delta$-aminolevulenic acid (ALA) as the precurser of heme was used as the dye and the measurement of concentration of PPIX in cells was assessed in a cancer cell culture. The metabolic precursor ALA was included in the incubation media for 24 hours to induce cellular accumulation of PPIX for the purpose of PDT. The distributions of initial PPIX concentration, $\mathrm{C}_{*}$ in $\mu \mathrm{g} / \mathrm{ml}$, photobleaching light dose, $\mathrm{H}_{\iota}$ in $\mathrm{J} / \mathrm{cm}^{\prime \prime}$, and photodtynamic dose, $\mathrm{D}_{\mu n t}$ which is defined as the number of photons absorbed by PPIX per $g$ of cells, were measured on 124 individual cells using video fluorescence microscopy. The results showed that the $\mathrm{H}_{6}$ was normally distributed with a mean $\pm \mathrm{SD}$ of $135 \pm 56 \mathrm{~J} / \mathrm{cm}$ using $488 \mathrm{~nm}$ light. The $\mathrm{C}_{0}$ and $\mathrm{D}_{p o r}$ were not normally distributed, with mean values (and ranges ) of $6(1-15) \mu \mathrm{g} / \mathrm{ml}$ and $5.2 \times 10^{19}\left(3 \times 10^{18}-2 \times 10^{29}\right)$ photons absorbed by PPIX per $\mathrm{g}$ cells $[\mathrm{ph} / \mathrm{g}]$, respectively. Individual PDT treatment of 131 cells via the microscope followed by 3 -day incubation and assay for colony formation allowed specification of the $\mathrm{D}_{*, n T}$ of individual cells destined for death of survival. The threshold $\mathrm{D}_{r, r}$ to achieve
\end{abstract}

(平成 7 年12月26日受理 平成 8 年 2 月21日揭載決定)

(Received December 26th 1995. Accepted February 21th 1996.) 
cell killing was not shrap, falling between $1 \times 10^{18}-30 \times 10^{18} \mathrm{ph} / \mathrm{g}$. In conclusion, a measurement system combined with an optical multichannel analyzer and a fluorescence microscope can be considered as a effective method for estimating PPIX concerntratio $\mathrm{n}$ in a cell.

Key words : Chemotherapy, photodynamic therapy, photobleaching, breast cancer cells, fluorescence microscopy

\section{邦文要旨}

癌の光化学療法 (PDT) は主にレーザと目的の癌細胞や組織に特翼的に吸收さ㣗る常光物

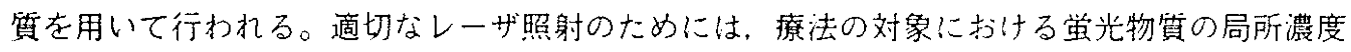
を知ることが必須である。本諭文では，アミノレブリン酸より細胞内でプロトポルフィリン IX ( PPIX ) を生台成させ蛍光物質として用い，培黄絸胞に対して $488 \mathrm{~nm}$ の光源を用いた PDTを実施し、各細胞内のPPIXの初期濃度 $\mathrm{C}$ 。光照射媓 $\mathrm{H}_{6}$ 。単位重䥣当たりの光子吸収個数

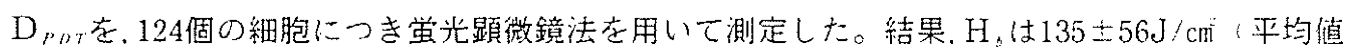


$10^{20}$ の範囲)(photons $/ g$ cells〕であった。さらに個々の細胞をPDT奏施後 3 日間培善し、つ

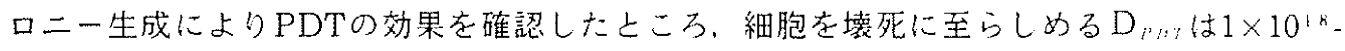
$20 \times 10^{18}[$ photons $/ g$ cells $) の$ 範囲であった。以上より本稿で提案した営光顕微鏡法はPPIX の漕度定量に有効であると考えられた。

\section{INTRODUCTION}

Administration of $\delta$-aminolevulenic acid(ALA), the metabolic precursor for the heme synthetic psthway, can induce the accumulation of protoporphyrin IX (PPIX) in cells": . Such ALA-induced PPIX has been currently under investigation in many centers for the purpose of photodynamic therapy(PDT) which is a light-activated chemotherapy for cancer and other indications ${ }^{3-6}$. PPIX serves as a photosensitizing agent for PDT. Light excitaion of PPIX results in the population of the first singlet state and in its conversion into a triplet state is able to transfer energy to molecular oxygen. This results in the formation of singlet oxygen, which causes cytotoxic reactions. Establishing effective protocols for PDT requires a knowledge of the local concentration of PPIX in a targeted cell culture of tumor.Since PPIX in the cell undegoes photodestruction, called photobleaching, during the irradiation of laser, the photobleaching light dose constant which is the product of the irradiance of the photobleachig light and the photobleaching time con- stant, is also required to predict the photodynamic dose experienced by the target tissue. The photodynamic dose, namely deposited energy per photon density, is defined as the number of photons absorbed by PPIX per $\mathrm{g}$ of cells, $\mathrm{D}_{r^{\prime} D}[\mathrm{ph} / \mathrm{g}]^{i}$. This parameter indicates the number of excited state PPIX molecules generated per unit mass of cells and is proportional to the amount of singlet oxygen tenarated which contributes to oxidative damage leading to cell death. The $\mathrm{D}_{i n}$ parameter provides an importnat dosimetric measure for comparison of the efficiency of different photosensitizers to achieve photodynamic action. Patterson et $\mathrm{al}^{7}$. illustrated that $D_{i n}$, was a constant value independent of the wavelength of irradiation in their study of PDT-induced necrosis in rat livers.

This paper reports the two parameters in a putatively homogeneous population of cancer cells in culture: (A) the initial concentration of PPIX in cells, $C_{0}[\mu \mathrm{g} /$ cell $]$, and $(B)$ the photobleaching light dose constant, $\mathrm{H}_{t}[\mathrm{~J} / \mathrm{cm}]$. The measurements involved quantitative video fluorescence microscopy 
of single cells during prolonged irradiation. The $\mathrm{C}_{6}$ and $\mathrm{H}_{6}$ were used to predict the photodynamic dose, $D_{P D T}$, photons absorbed by PPIX/g cells of $[\mathrm{ph} / \mathrm{g}]$, that would be attained in each cell after complete photobleaching of all PPIX. Furthemore, a colony formation study of cell survival is presented after individual irradiation of single cells via the microscope. The techniques allow specification of the indevidualized $D_{P D}$ of cells which were successfully killed and of cells which survived the treatment.

\section{MATERIALS AND METHODS}

\section{Cell cultures}

The cancer cell line used in the study was MTF7, cloned from a 7, 12-dimethyl-benz[a]-anthraceneinduced rat mammary adenocarcinoma, courtesy of Dr. Stephen P.Tomasovic, Department of Tumor Biology, M. D. Anderson Cancer Center ${ }^{8}$. The cells were grown in $\alpha$-MEM (Alpha-modified, Minimum Essential Eagle, Sigma Chemical Co., St. Louis, MO) supplemented with $10 \%$ fetal bovine serum (HyClone Laboratories Inc., Logan, UT) in monolayers in petri dishes.

ALA (Sigma Chemical Co., St. Louis, MO) was introduced into the culture media at various concentrations, specified later, and the cells were incubated as monolayers on petri dishes for $24 \mathrm{hr}$. The cell concentration in culture at harvest was $0.7 \times 10^{6}$ cells per perti dish which was not confluent.
At the time of the PPIX assay, the cells were loosened from 3 perti dishes by the addition of trypsin to the medium (0.25\%) and incubated for $5 \mathrm{~min}$ at $37^{\circ} \mathrm{C}$. The loosened cells were resuspended in phosphate buffer saline (PBS), centrifuged, and resuspented in $1 \mathrm{ml}$ of PBS, to yield $2 \times 10^{6}$ cells $/ \mathrm{ml}$.

Two cell preparations were studied : (Preparation A) Twenty $\mu \mathrm{l}$ of the cell suspeneion $\left(40 \times 10^{3}\right.$ cells $)$ were placed on a glass slide with a cover slip for fluorescence microscopy. (Preparation B)Cell digests were prepared by placing $1 \mathrm{ml}$ of PBS containig $2 \times 10^{4}$ cells into $2 \mathrm{ml}$ of Scitigest (Fischer Scientific), a solvent/digestant which yielded a clear solution after $18 \mathrm{hr}$. The cell digest was placed in a polystyrene cuvette for bulk fluorescence measurements using the OMA.

\section{Fluorescence assay for PPIX}

Two fluorescence measurements were conducted. (A) Video florescence microscopy $\left(F_{k, d}\right)$ measured single cells. (B) An optical-fiber fluorescence spectrophotometer $\left(\mathrm{F}_{\text {oms }}\right)$ measured cell digests. Comparisons of the two measurements together with calibration experiments using $\mathrm{F}_{o m_{a}}$ enabled calibration of the video $\left(\mathrm{F}_{i, d}\right)$.

\section{a. Fluorescence microscopy}

The level of PPIX in single cells was assayed by the fluorescence microscopy system shown in Fig.1. Considering the absorption of PPIX, the measurement system used a 488-nm argon iron

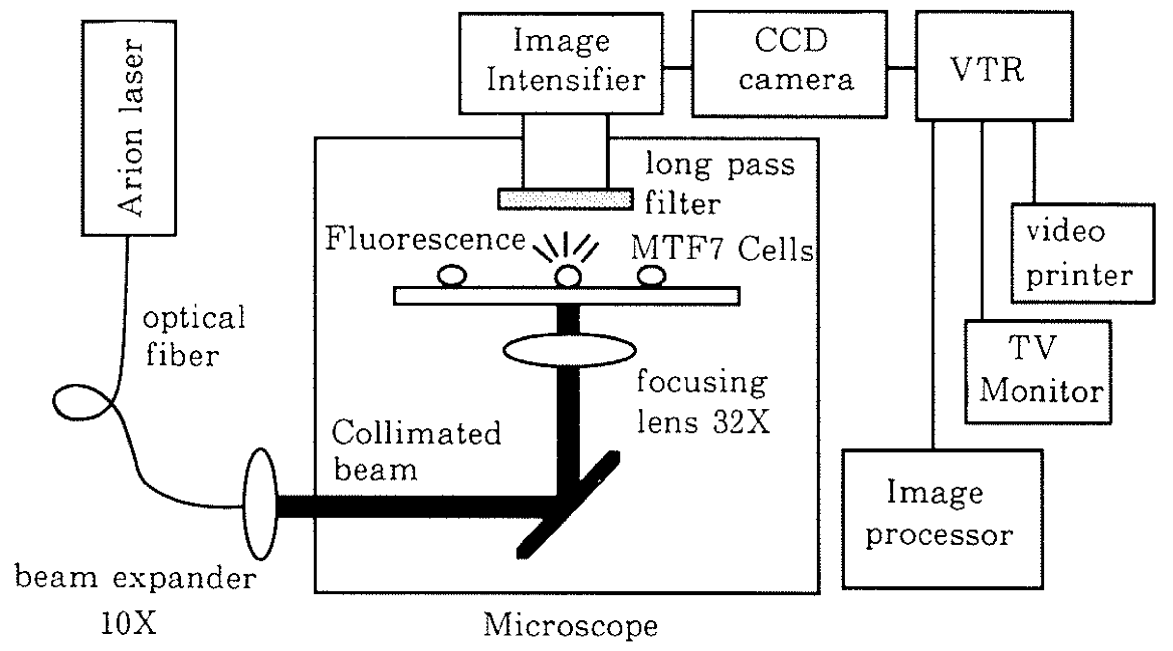

Figure 1 Fluorescence microscopy apparatus. An argon ion laser (488 $\mathrm{nm}$ ) excited cellular PPIX fluorescence and an intensified CCD camera viewed the emission through a $580-\mathrm{nm}$ long-pass filter. 
laser (Coherent, Inc., model Innova 90) delivered through an inverted microscope (Zeiss, Inc., model Axiovert $405 \mathrm{M}$ ) to excite PPIX fluorescence in individual cells. Fluorescence was observed through a 580-nm long-pass filter with an intensified CCD camara (Video Scope International Inc., VS2525 intensifier, CCD200E camara) and recorded by video tape (Panasonic, $A G-6300)$. The laser was delivered through an optical fiber whose termination was imaged through the microscope to yield a uniform-field beam in the image plane. The irradiance of the laser was $5.8 \mathrm{~W} / \mathrm{cmi}^{2}$ to avoid thermal damage of cells and the beam was $180 \mu \mathrm{m}$ in diameter. The recorded fluorescence image were sent to a personal computer (Macintosh) for acquisition and analysis using an image processing system (Image, NIH). The measurements were recorded as a porphyrin fluorescence score.

A porphrin fluorescence srore, $F_{t a}$ in laboratory units called [videl units/cell], was defined by the following :

$$
F_{n, d}=\mathrm{ANF}_{c a m e r a}
$$

where A was the cell cross-sectional area $\left[\mu \mathrm{m}^{2} /\right.$ cell $]$. $N$ was the number of pixels per unit area in the image processing system $[2.13$ pixels $/ \mu \mathrm{m}]$, and $F_{\text {camer a }}$ was the fluorescence intensity in laboratory units[video units/pixel].

\section{b. cell digest fluorescence measurements(OMA)}

Mesurements of PPIX in cell digests utilized a fluorescence spectrophotometer. The sysem used a nitrogen-dye laser (Laser Science, Inc., Newton, MA) at $420 \mathrm{~nm}$ delivered through an optcal fiber to excite cell fluorescence and an optical mutichannel analyzer (OMA) (Princeton Instruments, Inc., Trenton, NJ) to detect fluorescence. The same 600$\mu \mathrm{m}$-core-diameter fiber both delivered excitation and collected emission. The fiber was placed against the side of a polystyrene cuvette containing a cell digest (preparation B). The porphyrin fluorescence score $\left(F_{\theta} m_{0}\right)$ was determined by integrating the area under the fluotescence curve between 600-750 nm and normalizing by a standard reference which was the peak fluorescence of a fluorescein standard solution routinely measured to account for day-to- day variation in the system. The background $F_{n, m}$ for cells grown without PPIX was subtracted from all $F_{0 m a}$ measurements, and all values of $F_{n . . .}$ reported here have undergone such a background subtraction.

\section{c. Calibration experiments}

Microscope calibration

Cells were incubated for $24 \mathrm{hr}$ in various concentrations of ALA to yield a range of PPIX levels. Individual cells (preparation A) were measured with the video camara $\left(F_{1, d}\right)$. A cell digest (preparation $B)$ was measured with the fluorescence spectrophotometer $\left(F_{m,}\right)$. Figure 2 plots the PPIX fluorescence in the cell digest $\left(F_{* m o}\right)$ vs the PPIX fluorescence of the same cells measured by fluorescence microscopy $\left(F_{:, j}\right)$. The ralationship was



Figure 2 Calibration curve for PPIX fluorescence in a cell digest $\left(F_{o m a}\right)$ vs the $\mu g$ of PPIX added to the cell digest.

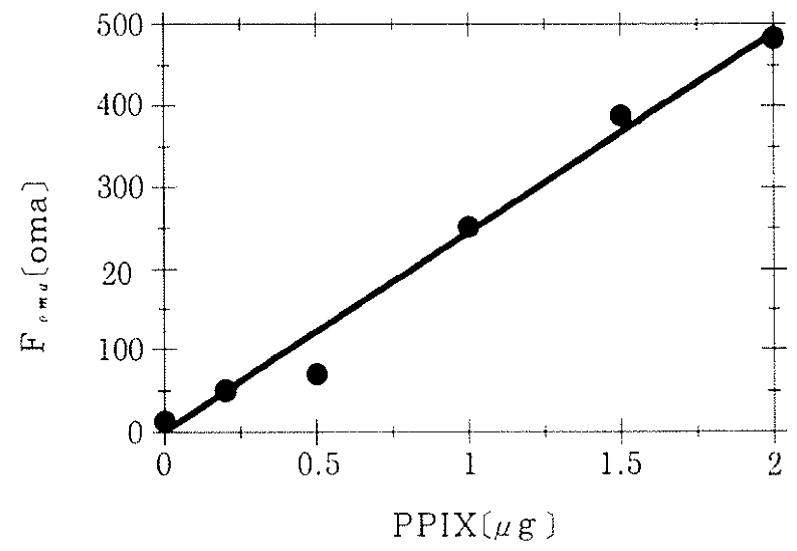

Figure 3 Calibration curve relating the PPIX fluorescence measured by spectrometer in a cell digest $\left(F_{a m a}\right)$ vs the fluorescence measured in cells by video microscopy $\left(\mathbf{F}_{x i d}\right)$. 


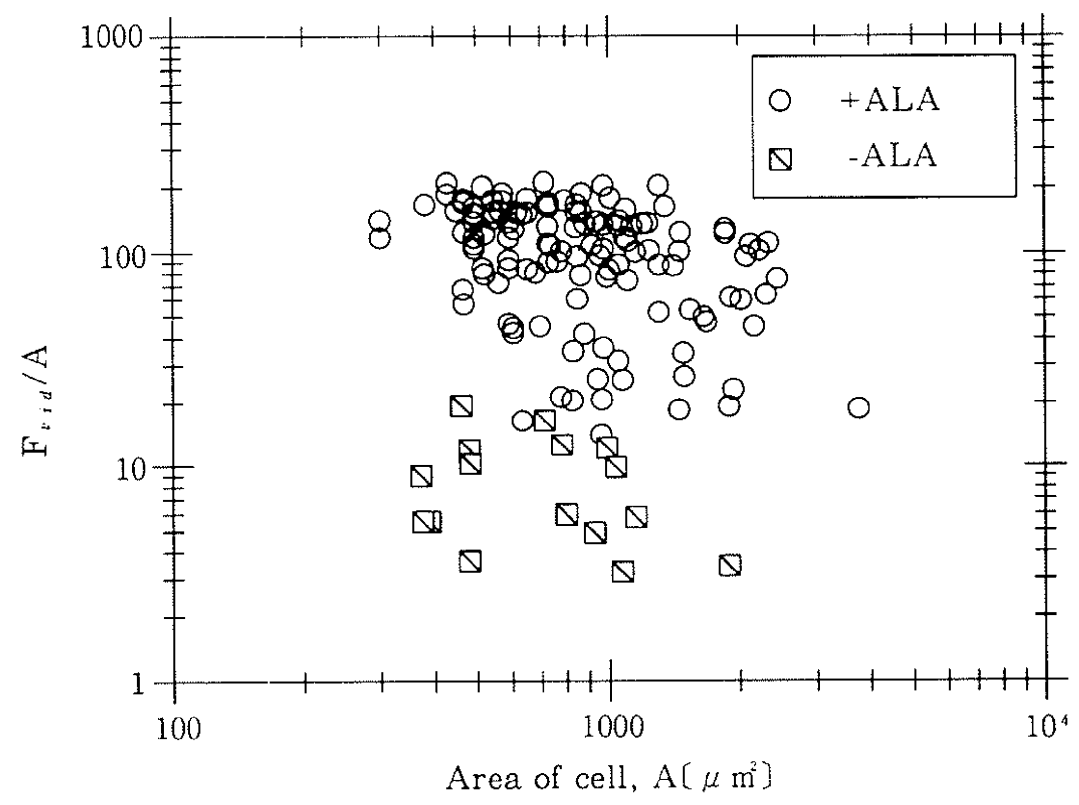

Figure 4 The brightness of cellular fluorescence as seen by the eye with a microscope through 580-nm long-pass filter, quantified by the video camara as $F_{v i d} / A$. The total fluorescence $\left(F_{n i d}\right)$ was distributed over the area of the cell (A). Data are plotted versus cell area. Incubation of cells in $A L A(+A L A)$ yieided about 10 -fold brighter fluorescence than cells grown without ALA (-ALA).

linear :

$$
\mathrm{F}_{0 m a}=\mathrm{A}+\mathrm{c}_{i, d}^{i m a} \mathrm{~F}, \sigma
$$

where $\mathrm{A}$ is the $\mathrm{y}$-intercept (10.5[oma]), and $\mathrm{c}_{n: 0}$ is the slope $(0.00044$ [oma/(video units/cell)]).

OMA calibration

In a second experiment, the cells not grown in ALA were prepared as a cell digest (preparation B). Known amounts of PPIX $[\mu \mathrm{g}]$ were added to the digest and $F_{a m a}$ measurements made. Figure 3 plots the fluorescence of a cell cigest $\left(F_{a m a}\right)$ vs the amount of added PPIX $[\mu \mathrm{g})$ yielding a linear relation with a slope, $c_{\mu \prime \prime \prime}^{\prime m}$. equal $249[$ [oma $/ \mu$ g PPIX].

Combining the above two calibration experiments, the relationship between a video measurement, $\mathrm{F}_{i, d}$, and the cellular PPIX concentration, $\mathrm{C}_{i}[\mu \mathrm{g} /$ ml]. was:



$\mathrm{N}$ was the number of cells in the cell digest $\left(2 \times 10^{\prime \prime}\right.$

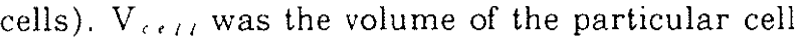
measured [ml/cell]. Each cell's volume (V) was estimated based on the cell's diameter obserbed in the two-dimensional image acquired by the camara, assuming a spherical shape for the nonadherent cell. Experimentaly, the $C_{\text {。 }}$ values were specefied by Eq. 3 from the $F_{1}$ values at the start of irradiation before significant photobleaching could

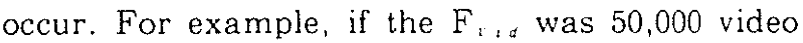
units/cell, and the $\mathrm{V}_{1, \ldots}$, was $2.6 \times 10^{-8} \mathrm{ml} /$ cell, then the $\mathrm{C}$, was $2.5 \mu \mathrm{g} / \mathrm{ml}$ within the cell.

\section{Colony formation}

Cells in mid-log phase growth were plated onto petri dishes at a low density, about 200 cells per plate, and incubated in $200 \mu \mathrm{g} / \mathrm{ml}$ ALA for $24 \mathrm{hr}$. The plates had grids drawn on their bottom surface to facilitate identification of cells at a given position. A sampling of cells was observed with the inverted fluorescence microscope during the individual irradiation of single cells. 36 cells were given $20 \mathrm{~J} / \mathrm{cm}$ ? 

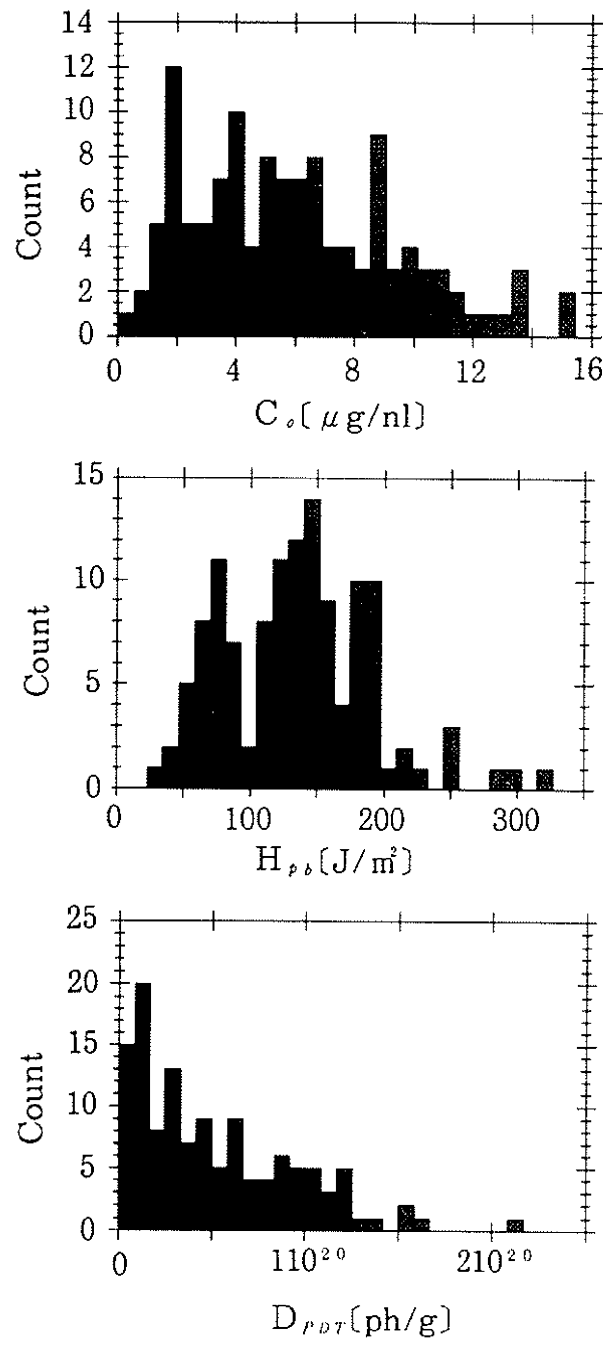

Figure 5 Histograms of (top) the initial concentration fo PPIX, (middle) the photobleaching light dose constant, and (bottom) the photodynamic dose achieved by complete photobleaching of the cellular PPIX.

and 81 cells were given $300 \mathrm{~J} / \mathrm{cmi}$. Video recordings measured the initial $\mathrm{C}_{*}$ of each cell and the dacay due to photobleaching. Because the perti dish imposed a relatively high amount of autofluorescence, only the initial photobleaching could be documented, however the values of $\mathrm{H}_{6}$ obtained were similar to the previous study of cells on glass. In this study, the mean \pm standard deviation for $\mathrm{H}_{6}$ was 102 $\pm 51\left[\mathrm{~J} / \mathrm{cm}^{2}\right]$. Because the cells were adherent to the perti dish, the $V_{\text {c . I }}$ was calculated by assuming a hemispherical shape. The $\mathrm{D}_{P_{D T}}$ of each cell was calculated using Eq. a-3, shown in Appendix, accounting for the radiant exposure utilized ( 20 or $300 \mathrm{~J} / \mathrm{cm}^{3}$ ). After exposure, the cells were incubated for 3 days, then scored for signs of successful colony formation .

\section{RESULTS}

When one observes a fluorescent cell by eye through the microscope, the total fluorescence is distributed over the cell cross-sectional area, $A\left(\mu \mathrm{m}^{\prime}\right)$, in the field of view to yield a particular brightness, which can be expressed as $F_{: d} / A$ [pixel units/ $\left.\mu \mathrm{m}^{2}\right]$. Figure 4 plots $F_{:, d} / A$ versus $A$. Cells not incubated in $A L A(n=16)$ had a mean value of 8.7 , and cells incubated in ALA $(n=124)$ had a mean value of 107

Figure 5 shows the histograms of the initial PPIX concentration, $\mathrm{C}_{0}(\mu \mathrm{g} / \mathrm{ml})$, the photobleaching light dose, $\mathrm{H}_{b}(\mathrm{~J} / \mathrm{cm})$, and the photodynamic dose, $\mathrm{D}_{r r o r}$ [ph/g]. The mean (and range) of $C$. was 6.0 (1-15) $\mu \mathrm{g} / \mathrm{ml}$. Control cells not grown in 5ALA showed 0.52 $[\mu \mathrm{g} / \mathrm{ml}]$. Assuming these $\mathrm{C}$, values were primarily due to PPIX and that background non-porphyrin auto-fluorescence in the $600-750 \mathrm{~nm}$ range was negligible, the amount of PPIX induced by 5 ALA was about ten times the amount of endo-genous PPIX in cells. The $H_{\text {, was }} 135$ (25-300) J/ $\mathrm{cnt}^{2}$, which was surprisingly variable. The maximum $\mathrm{D}_{r^{\prime}}$, obstained after complete photobleaching of PPIX was calculated to be $5.2 \times 10^{19}\left(3 \times 10^{18}-2 \times 10^{20}\right)$ $[\mathrm{ph} / \mathrm{g}]$.

Figure 6 shows the correlation between $D_{l, b r}$ and $\mathrm{C}_{0}$, and the mean values of $5.2 \times 10^{19} \mathrm{ph} / \mathrm{g}$ and $6.0 \mu \mathrm{g} / \mathrm{ml}$, respectively. The slope should be $\varepsilon \mathrm{H}_{b} /$ $\mathrm{b} \rho$, or $8.7 \times 10^{1 \mathrm{~s}}(\mathrm{ph} / \mathrm{g}) /(\mu \mathrm{g} / \mathrm{ml})$, as indicated by the solid line. The noise derives from variations in the experementally measured $\mathrm{H}_{b}$ and the measured cell size used to cstimate $\mathrm{V}_{, \ldots /,}$ for ealculation of $\mathrm{C}_{0}$. The slope overestimates the data at low $\mathrm{C}$, and underestimates the data at high $\mathrm{C}_{*}$.

Figure 7 shows bleb formation, an indicator for photodynamic damage to cell membranes, in a cell after $350 \mathrm{~J} / \mathrm{cm}^{3}$ of laser exposure which was sufficient to cause nearly complete photobleaching of PPIX. Before the cell was exposed to the laser (Fig. 7a), there was no bleb. After exposure (Fig.7b), the cell displayed a bleb at the $100^{\prime}$ clock position. The bleb itself had no PPIX fluorescence.

The results of the colony formation study are shown in Fig. 8. The calculated $D_{i^{*}, t}$ for each cell is specified by the $y$-axis. In the study, 36 cells re- 


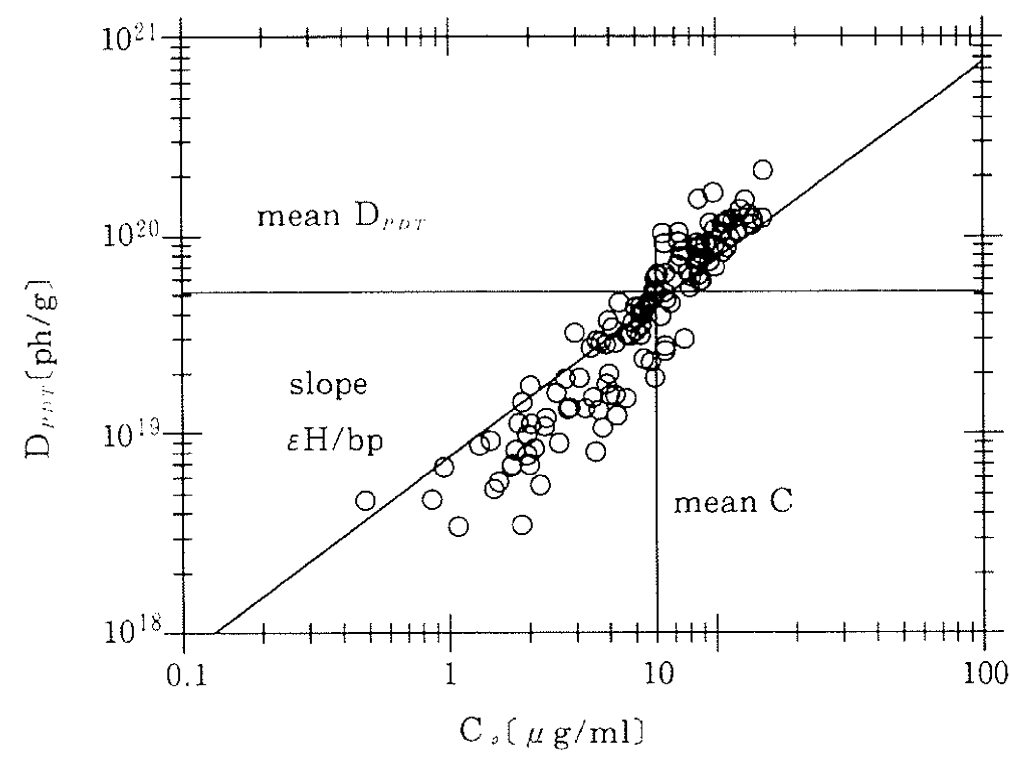

Figure 6 Correlation of the maximum photodynamic dose $\left(D_{P D T}\right)$ and the PPIX concentration in cells $\left(C_{0}\right)$, with mean values $5.2 \times 10^{19} \mathrm{ph} / \mathrm{g}$ and $6 \mu \mathrm{g} / \mathrm{ml}$, respectively. The slope should be $\varepsilon \mathrm{H}_{p o} / \mathrm{b} \rho$, as described in Eq. a-4.

a



$\mathrm{b}$

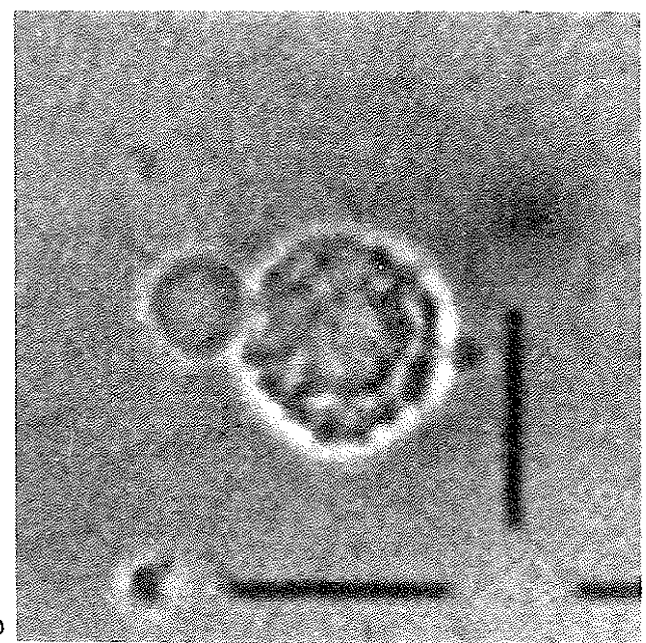

Figure 7 Bleb formation in cell exposed to laser radiation that completely photobleaches the cellular PPIX. (a) Cell before exposure. (b) Cell after exposure. ceived $20 \mathrm{~J} / \mathrm{crli}$ and 81 cells received $300 \mathrm{~J} / \mathrm{cm}$ radiant exposure. After 3 days incubation, the occurence of cell colonies was scored. The cells killed by PDT and those that survived are compared. The $D_{n n t}$ obtained with $300 \mathrm{~J} / \mathrm{cm}$ was higher than with $20 \mathrm{~J} / \mathrm{cm}^{2}$, of course, and the rate of colony formation was lower at the high exposure than the low exposure, $3 / 81(3.7 \%)$ vs $8 / 36(22 \%)$, respectively. However, there was not a sharp threshold value of $D_{P n T}$ which demarcated death from survival. Some dosages were as low as $1 \times 10^{18}$ but achieved cell kill. Other dosages were as high as $3 \times 10^{19}$ and failed to kill. The threshold $D_{p n r}$ for killing falls in the range of $1 \times 10^{18}-3 \times 10^{: 3}$. Within that range, most cells were killed but a significant fraction survived. This work continues to explore celling killing vs survival at low $\mathrm{D}_{n, i}$ exposures.

\section{DISCUSSIONS}

PDT is a form of light-activated chemotherapy for the treatment of malignant neoplasia. Relatively non-toxic photoactive compounds will preferentially accumulate in malignant tissues and yield a phototoxic effect when stimulated by the absorption of photon. A major advantage of ALA induced PPIX is its rapid conversion into subsequent metabolites along the heme synthetic pathway. The elevated PPIX concentration is transient only 24 hours in 


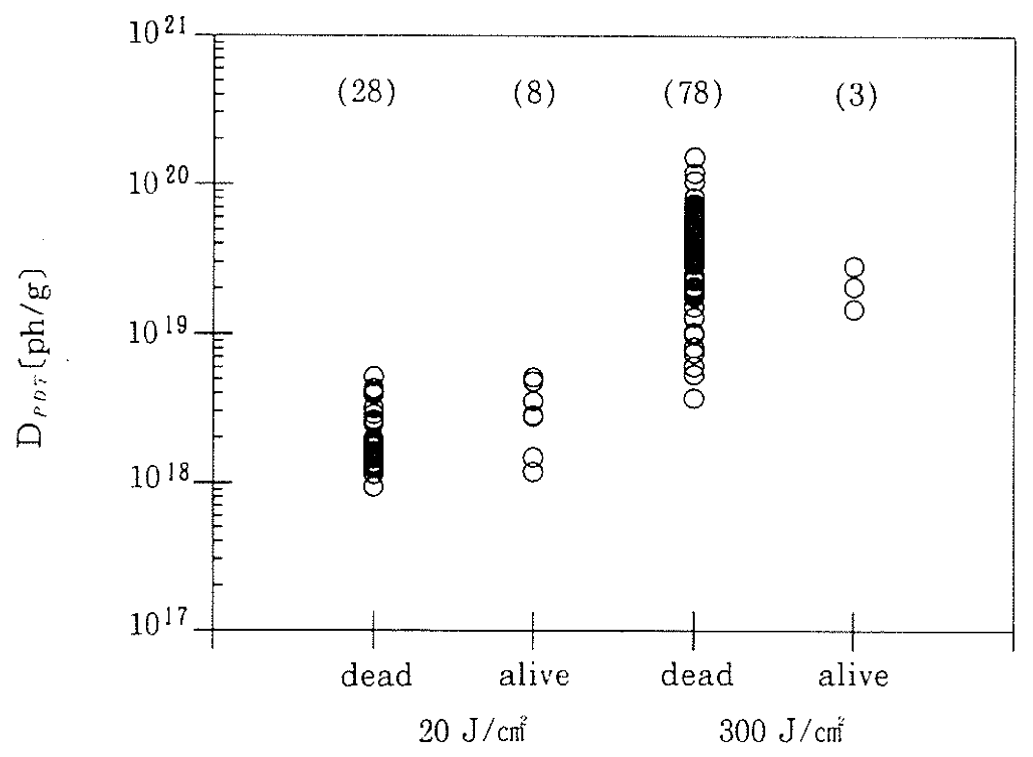

Figure 8 Colony formation study. Cells individually received light exposure while video recordings documented $C_{a}$ and $\mathrm{H}_{p b}$, allowing the $\mathrm{D}_{P D T}$ of indivudual cells to be calculated. Cells received either 20 or $300 \mathrm{~J} / \mathrm{cm}^{2}$ at $488 \mathrm{~nm}$ wavelength. The $D_{r n r}$ values of cells that died and cells that aurvived to form colonies are shown. The lowest dose that killed was about le18 $\mathrm{ph} / \mathrm{g}$ and the highest dose that failed to kill was $3 \mathrm{e} 19 \mathrm{ph} / \mathrm{g}$.

vitro. Therefore, the side effect of prolonged photosensitization which is a consideration with the use of administered porphyrin, is avoided. This study of ALA induced PPIX aimed to investigate the variation of PDT dose, deposited energy per photon density, in culture cells for estimating the efficacy of PDT for tissue by using the fluorescence micro. scopy. The fluorescence microscopy developed in this work can measure the initial concentration and the photobleaching time constant simultaneously. In addition to this measurement method,two calibration methods were developed to assay the concentration of PPIX cell by cell. The result of the total fluorescence distributed over the cell varied widely depending on the cross-sectional area. The area of the cell varied but the normalized value, $\mathrm{F}_{E, d} / \mathrm{A}$, showed the difference between tne cells with ALA and cells without ALA. This result showed that the measurement of each cell cross sectional area was essential for estimating the fluorescence intensity from a cell. The distribution of the initial
PPIX concentration, C. $(\mu \mathrm{g} / \mathrm{ml})$, and the photobleaching light dose, $\mathrm{H},(\mathrm{J} / \mathrm{cri})$. showed that both values also widely varied depending on each cell.

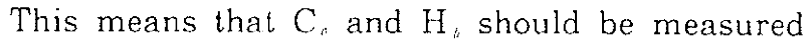
cell by cell to avoid errors caused by the difference of PPIX synthesis or cell cycle in each cell before PDT. Next, as shown in Fig. 6, the apparently homogeneous population of cells is behaving so hetero. geneously with respect to PPIX accumulation and photobleaching. The cell cycle may effect this result but further investigation is needed. The concept of a threshold photodynamic dose was studied using another photosensitizer, aluminum chlorosulphonated phthalocyanine $(\text { AISPC })^{\top}$. They reported a threshold $D_{\ldots,}$ of $3.8 \times 10^{1:}$ for achieving necrosis in rat liver. There authours also estimated a threshold $D_{i \%}$ of $8.6 \times 10^{\text {? }}$ for the photosensitizer Photof rin II to achive necrosis in human tumors, based on the work of Potter. Recently, Chen et al" ". have reported a threshold $D_{1 ., 2}$ of $4.0 \times 10^{\text {" f for }}$ Photof rinll to achieve necrosis in dog prostate. The 
estimated range for a threshold $D_{p u r}$ of $1 \times 10^{1:}$ $3 \times 10^{19}$ reported for PPIX in this paper is consistent with the values for Photofrin II. PPIX appears ralatively efficient in achieving photodynamic kill. ing of cells. ALA induced PPIX synthesis directly within the target cancer cells. In contrast, administration of pre-synthesized porphyrin relies on transport by diffusion from the vascular space into the cancer cells. The difference of the pathway may couse the relatively higy efficiency of PPIX.

\section{CONCLUSION}

The amount of PPIX attained by the cells ranged between $1-15 \mu \mathrm{g} / \mathrm{g}$ cells, with a mean value of 6.0 $\mu \mathrm{g} / \mathrm{g}$ cells. The photobleaching dose constant was $135 \pm 56 \mathrm{~J} / \mathrm{cm}^{2}$. The photodynamic dose obtainable after complete photobleaching ranged between $2 \times$ $10^{18}-5 \times 10^{19}$ with a mean value of $5.2 \times 10^{19}$, photons absorbed by PPIX per g cells]. A colony formation study indicated that the threshold $D_{1, n}$ required for cell killing fell in the range of $1 \times 10^{18}-3 \times 10^{19}$.

\section{ACKNOWLEDGMENTS}

The aouthor thanks Dr. Steven L. Jacques for his support. The MTF7 cell line was provided by Dr. Stephen P. Tomasovic, Department of tumor biology. M. D. Anderson Cancer Center. The author also thanks Tom Rodriguez and Jon Schwarz for techinical assistance.

\section{REFERENCES}

1. Mailk Z. and H. Lugaci : Destruction of erthroleukaemic cells by photoactivation of endoge nous porhyrins, Br. J. Cancer, 54: 589-595, 1987.

2. Ades I. Z. : Heme production in animal tissues : The regulation of biogenesis of $\delta$-aminolevulenate synthetase, Int. J. Biochem., 22 : 575578, 1990.

3. Dimitrios X. G. D., K. C. Kennedy and R. H. Potteir:Phototoxic damage to sebaceous glands and hair follicles of mice after systemic admi. nistration of 5-aminolerulinic acid correlateswith localized protoporphyrin IX fluorescence, Amer. J. Pathology, 136 : 891-897. 1990.
4. Bedwell J., A. J. MacRobert, D, Philips and S. G. Bown : Fluorescence distribution and photodynamic errect of ALA-induced PPIX in the DMH rat colonic tumor model, Br. J. Cancer, $65: 818-824,1993$.

5. Loh C. S., J. BeA. J. MacRobert, N. Krasner, D. Philips and S. G. Bown : Photodynamic therapy of the normal rat stomace : a comparative study between disulphonated aluminum phthalocyanine and 5-aminolaevulinic acid, Br. J. Cancer, 66:452-462, 1992.

6. He X-Y, S. L. Jacques and S. L. Thomsen: In vitro cellular effects of $\delta$-aminolevulenic acid sensitized pyoto-dynamic therapy, In Proceedings of the Soc. Photo-Opt. Instr. Eng. (SPIE). $2133: 18-27,1994$.

7. Patterson M. S., B. C. Wilson and R. Graff : In vivo tests of the concept of photodynamic threshold dose in normal rat liver photosensitized by aluminum chlorosulphonated phthalocyanine, Photochem. Photobiol., 51 : 343-349, 1990.

8. Tomasovic S. P. : Hetero-geneous response and clonal drift of sensetıvities of metastatic 13672 NF mammary adenocarcinoma clones to $\gamma$ radiation in vitro, Cancer Res., $43: 6-10,1983$

9. Potter W. R. : PDT dosimetry and response, In Proceedings of the Soc. Photo-Opt. Instr. Eng. (SPIE), 1065 : 88-99, 1989.

10. Chen Q., S. Shetty, L. Heads, D. Schultz. J. Cemy, H. Chen and F. W. Hetzel : Photodynamic therapy of normal canine prostate, Abstract 167,5th International Photodynamic Association Biennial Meeting. Amelia Ialand, FL, Sept. 21$24,1994$.

\section{APPENDIX}

\section{Photobleaching and fluorescence}

Photobleaching of PPIX in a cell is expected to follow first-order kinetics with respect to the radiant exposure, $\mathrm{H}\left[\mathrm{J} / \mathrm{cm}^{2}\right]$, of the single cell. Assume that the initial distribution of PPIX is uniform in a cell at a concentration $\mathrm{C}_{0}(\mu \mathrm{g} / \mathrm{ml})$. The PPIX in the 
cell undergoes photodestruction, called photo-

bleaching, and $\mathrm{C}_{\text {o decays as : }}$

$$
C(t)=C_{0} \exp (-t / \tau)
$$

where

$$
\tau=\frac{\mathrm{Hb}}{\mathrm{E}}
$$

The photobleaching time constant, $\tau[s]$, depends on the irradiance of the photobleachig light, ECW/ $\left.\mathrm{cm}^{2}\right]$, and the photobleaching dose constant, $\mathrm{H}_{b}[\mathrm{~J} /$ $\left.\mathrm{cm}^{2}\right]$. In our experiments, we measured $\tau$ at a specified $\mathrm{E}$ and deduced $\mathrm{H}_{n}$.

\section{The photodynamic dose}

The photodynamic dose, $D_{\mu n t}$, depends on the irradiance, $\mathrm{E}$, and the concentration of PPIX, $\mathrm{C}_{2}$, but this product must be integrated over the exposure time, $\mathrm{T}$, since photobleaching depletes the PPIX according to Eq. a-1. The integral is :

$$
\begin{gathered}
\mathrm{D}_{p D T}=\frac{\varepsilon}{\mathrm{bq}} \int_{0}^{T} \mathrm{C}_{0} \exp (-\mathrm{t} / \tau) \mathrm{Edt} \\
=\frac{\varepsilon \mathrm{C}_{0} \mathrm{E} \tau}{\mathrm{b} \rho}(1-\exp (-\mathrm{t} / \tau))=\frac{\varepsilon \mathrm{C}_{o} \mathrm{H}_{b}}{\mathrm{~b} \rho}(1-\exp (-\mathrm{H} / \mathrm{H}))
\end{gathered}
$$

where $\varepsilon$ is the extinction coefficient of PPIX at $488 \mathrm{~nm}\left[0.023 \mathrm{~cm}^{-1} /(\mu \mathrm{g} / \mathrm{ml})\right], \mathrm{b}$ is the energy per photon at $488 \mathrm{~nm}\left(4.07 \times 10^{-19} \mathrm{~J} /\right.$ photon $), \rho$ is the density of a cell $[\sim 1.0 \mathrm{~g} / \mathrm{ml}], C(t)$ is the PPIX concentration as it photobleaches, $\mathrm{E}$ is the irradiance $\left[\mathrm{W} / \mathrm{cm}^{2}\right], T$ is the exposure time $[\mathrm{s}], \mathrm{H}$ is the radiant exposure equal to $\mathrm{ET}[\mathrm{J} / \mathrm{cri}]$, and $\mathrm{H}_{b}[\mathrm{~J} /$ $\left.c n^{\prime}\right]$ is the photobleaching exposure that reduces $C$ (t) by a factor $1 / e$.

If the PPIX is completely photobleached $(t>>\tau$. or $\mathrm{H}>>\mathrm{H}_{b}$ ), the maximum $\mathrm{D}_{, \cdot,}$ obtained is proportional to the product $\mathrm{C}_{0} \mathrm{H}_{b}$.

$$
\mathrm{D}_{P D T} \text { for complete photobleaching }=\frac{\varepsilon \mathrm{C}_{\cdot} \mathrm{H}_{b}}{\mathrm{~b} \rho}(\mathrm{a}-4)
$$

This study measured both $\mathrm{C}$, and $\mathrm{H}_{t}$ for individual cells. The maximum $\mathrm{D}_{r n}$ obtainable in individual cells was calculated using Eq.a-4. In the colony formation study in this paper, cells received a radiant exposure of either 20 or $300 \mathrm{~J} / \mathrm{cm}^{2}$ and Eq. a-3 was used to calculate the true $D_{p D r}$ of each cell. 